Indoor pollutants and asthma in children

\section{The great indoors}

\section{B Brunekreef}

\section{Further evidence for the role of indoor pollutants in the development of childhood asthma}

$\mathrm{T}$ he prevalence of asthma (especially childhood asthma) is high, and children in particular spend a lot of time in their homes. In addition, our homes contain many pollutants so, understandably, we'd like to know to what extent pollutants in the home environment cause and/or worsen asthma in our children.

\section{WHAT DO WE KNOW?}

In many children asthma is closely associated with allergy, and many asthmatic children are allergic to dust mite and pet allergens. For them, reduction of exposure is likely to be beneficial. But does this mean that mite and pet exposure causes asthma? This issue is surprisingly complex. Whereas studies suggest that exposure to specific allergens increases sensitisation to those allergens, this does not necessarily mean that such exposures also increase the incidence of asthma. ${ }^{12}$ Some studies even suggest that early life exposure to pets (and other animals) may reduce the incidence of asthma. ${ }^{3-7}$

Compared with the already complex role of exposure to allergens and other biological contaminants, the evidence with respect to chemicals such as nitrogen oxides, sulfur oxides, and particles produced by combustion appliances, environmental tobacco smoke, and volatile organic compounds (VOCs) is even less clear.

In this issue of Thorax two new studies from Australia attempt to provide further evidence for the role of unvented heating appliances and of VOCs, respectively. Phoa et $a l^{8}$ retrospectively collected data on unvented heater exposure in a sample of children aged 8-11 years. Early-but not current-exposure to unvented space heaters was found to be associated with airway hyperresponsiveness and wheeze. Rumchev et al conducted a case-control study in young children and found that children aged 636 months, discharged from a hospital emergency department with a diagnosis of asthma, had higher concentrations of VOCs in their homes than control children living in the same community.
WHAT EVIDENCE CAN WE GLEAN FROM THESE NEW STUDIES? Effect of gas heaters on development of childhood asthma The study by Phoa et al was questionnaire based and grouped all sorts of "fume emitting" space heaters into one category-including gas heaters, kerosene heaters, open fireplaces, and wood stoves, each of which have distinctly different patterns of emissions of noxious substances. No measurements of pollutants were performed in the homes. Flued gas heaters, open fires, and wood stoves were all included in the fume emitting category, whereas it is likely that these are connected to chimneys and flues which would prevent most of the emissions from entering the indoor space. Adjustment for socioeconomic status (a likely covariate of flueless heater use) was not attempted, so some uncertainty remains about the extent to which the findings could be attributed in part to differences in socioeconomic status. The authors reported no association between asthma and current use of flueless heaters, but the analysis presented adjusted for the use of flueless heaters early in life. If there was a substantial correlation between early and current use of flueless heaters, this may mean that the lack of association with current heater use is to some extent due to overadjustment.

Unvented space heaters, fireplaces, and wood stoves have been studied before by several investigators. In a small study Cooper and Alberti ${ }^{10}$ found no effect on the lung function of healthy residents of homes with kerosene heaters. In a study in small children Triche et $a l^{11}$ found a slight increase in cough with the use of kerosene heaters and wood stoves and slightly more wheeze with the use of unvented gas heaters in the home. In a study from Seattle neither asthma nor wheeze in 5-9 year old children was found to be related to the use of either gas heaters, wood stoves or kerosene heaters. ${ }^{12}$ A prospective study from Tasmania did find a relationship between gas heater usage in the first year of life and asthma at the age of 7 years. ${ }^{13}$ A large study from Finland found a negative association between the use of wood stoves and asthma outcomes, but argued that this was because wood stoves were used more on traditional farms. The association disappeared after adjustment for living on a farm. ${ }^{14}$ Wood smoke is a well known respiratory irritant, and the use of wood stoves was found to be related to lower respiratory tract illness in a case-control study in small children. ${ }^{15} \mathrm{~A}$ study conducted among a panel of asthmatics found that subjects had more symptoms of cough and shortness of breath on days with reported use of gas stoves, fireplaces or wood stoves. ${ }^{16}$ Although the evidence is not entirely consistent, it is clear that unvented combustion appliances increase the exposure of inhabitants to combustion products to a sufficient extent to cause exacerbations and, perhaps, induction of respiratory diseases and symptoms. The study by Phoa et al adds to this evidence, albeit with less specificity than previous studies.

\section{Effect of VOCs on development of childhood asthma}

Rumchev et al found differences in indoor VOC concentrations between children with asthma and controls. This was a study in very young children at an age when the diagnosis of asthma is notoriously difficult. Measurements of VOCs were of short duration only (8 hours), but this is likely to lead to random misclassification primarily which would reduce differences between cases and controls. More "asthma" cases than controls reported recent indoor painting which probably shifted the VOC concentrations upwards, and no attempt was made to investigate differences between cases and controls after exclusion of subjects reporting recent indoor painting.

Few studies have addressed the effects of indoor exposure to VOCs on respiratory health. The focus in experimental studies has mostly been on sensory and neurological effects, observed at rather higher concentrations than those measured by Rumchev et al (median $36 \mu \mathrm{g} / \mathrm{m}^{3}$, maximum $600 \mu \mathrm{g}$ / $\mathrm{m}^{3}$ ). In the experimental studies by Molhave and others, the concentrations tested have typically been in the range $3-25 \mathrm{mg} / \mathrm{m}^{3}$ and, more often than not, no effects were seen at the lower end of this range..$^{18}$ Occupational studies among painters other than spray painters (who may be exposed to isocyanates) have provided evidence of increased asthma rates. ${ }^{19}$ However, a study comparing painters using water based paints with VOC exposures in the $1-3 \mathrm{mg} / \mathrm{m}^{3}$ range with painters using solvent based paints with VOC exposures in the $100-380 \mathrm{mg} / \mathrm{m}^{3}$ range 
found evidence of increased airway symptoms in the latter group only. ${ }^{20} \mathrm{~A}$ recent large study from the UK ${ }^{21}$ failed to document any effects of VOCs on persistent wheezing illness in school children at total VOC concentrations that were higher than in the study by Rumchev et al, but a study from Leipzig found that early life exposure to low concentrations of 25 selected VOCs related to house painting was associated with increased respiratory infections in infants. ${ }^{22}$ Other studies have suggested that VOC emissions from recent house redecorations and floorings might be related to asthma-like symptoms. $^{23}{ }^{24}$ Whether such associations reflect direct effects of indoor VOCs at low concentrations or, for example, confounding by traffic related pollutants covarying with indoor VOCs ${ }^{25}$ remains to be seen.

The issue of whether indoor VOCs are a risk factor for asthma in children therefore seems still to be largely undecided. In view of the methodological difficulties outlined above, prospective studies are more likely to produce progress in deciding whether we need to worry about indoor VOCs as determinants of asthma at the relatively low concentrations typically encountered in the home environment.

Thorax 2004:59:729-730.

doi: 10.1136/thx.2004.024091

Correspondence to: B Brunekreef, PhD, Professor of Environmental Épidemiology, Institute for Risk Assessment Sciences, Utrecht University, P O Box 80176, 3508 TD Utrecht, The Netherlands; b.brunekreef@iras.uu.nl

\section{REFERENCES}

1 Lau S, Illi S, Sommerfeld C, et al. Early exposure to house-dust mite and cat allergens and development of childhood asthma: a cohort study. Multicentre Allergy Study Group. Lancet 2000;356:1392-7.

2 Wahn U, Lau S, Bergmann R, et al. Indoor allergen exposure is a risk factor for sensitization during the first three years of life. J Allergy Clin Immunol 1997;99:763-9.

3 Almqvist C, Egmar AC, Hedlin G, et al. Direct and indirect exposure to pets - risk of sensitization and asthma at 4 years in a birth cohort. Clin Exp Allergy 2003;33:1190-7.

4 Anyo G, Brunekreef B, de Meer G, et al. Early, current and past pet ownership: associations with sensitization, bronchial responsiveness and allergic symptoms in school children. Clin Exp Allergy 2002;32:361-6.

5 de Meer G, Toelle BG, Ng K, et al. Presence and timing of cat ownership by age 18 and the effect on atopy and asthma at age 28. J Allergy Clin Immunol 2004;113:433-8.

6 Oryszczyn MP, Annesi-Maesano I, Charpin D, et al. Allergy markers in adults in relation to the timing of pet exposure: the EGEA study. Allergy 2003;58:1136-43.

7 Svanes C, Heinrich J, Jarvis D, et al. Pet-keeping in childhood and adult asthma and hay fever: European community respiratory health survey. J Allergy Clin Immunol 2003;1 12:289-300.

8 Phoa $\mathrm{L}$, Toelle BG, Ng K, et al. Effects of gas and other fume emitting heaters on the development of asthma during childhood. Thorax 2004;59:741-5.

9 Rumchev K, Spickett J, Bulsara M, et al. Association of domestic exposure to volatile organic compounds with asthma in young children. Thorax 2004;59:746-51.

10 Cooper KR, Alberti RR. Effect of kerosene heater emissions on indoor air quality and pulmonary function. Am Rev Respir Dis 1984;129:629-31.

11 Triche EW, Belanger K, Beckett W, et al. Infant respiratory symptoms associated with indoor heating sources. Am J Respir Crit Care Med 2002;166:1105-11.

12 Maier WC, Arrighi HM, Morray B, et al. Indoor risk factors for asthma and wheezing among Seattle school children. Environ Health Perspect 1997:105:208-14.

13 Ponsonby AL, Couper D, Dwyer T, et al. The relation between infant indoor environment and subsequent asthma. Epidemiology 2000;11:128-35.

14 Kilpelainen M, Koskenvuo M, Helenius $\mathrm{H}$, et al. Wood stove heating, asthma and allergies. Respir Med 2001;95:911-6.

15 Morris K, Morgenlander M, Coulehan JL, et al. Wood-burning stoves and lower respiratory tract infection in American Indian children. Am J Dis Child 1990;144:105-8.

16 Ostro BD, Lipsett MJ, Mann JK, et al. Indoor air pollution and asthma. Results from a panel study. Am J Respir Crit Care Med 1994;149:1400-6.

17 Molhave L. Indoor climate, air pollution, and human comfort. J Expos Anal Environ Epidemiol 1991; 1:63-81

18 Hudnell HK, Otto DA, House DE, et al. Exposure of humans to a volatile organic mixture. II. Sensory. Arch Environ Health 1992;47:31-8.

19 Kogevinas M, Anto JM, Sunyer J, et al. Occupational asthma in Europe and other industrialised areas: a population-based study European Community Respiratory Health Survey Study Group. Lancet 1999:353:1750-4.

20 Wieslander G, Norback D, Edling C. Airway symptoms among house painters in relation to exposure to volatile organic compounds (VOCs) - a longitudinal study. Ann Occup Hyg 1997:41:155-66.

21 Venn AJ, Cooper M, Antoniak M, et al. Effects of volatile organic compounds, damp, and other environmental exposures in the home on wheezing illness in children. Thorax 2003:58:955-60.

22 Diez U, Kroessner T, Rehwagen M, et al. Effects of indoor painting and smoking on airway symptoms in atopy risk children in the first year of life results of the LARS-study. Leipzig Allergy High-Risk Children Study. Int I Hyg Environ Health 2000:203:23-8.

23 Jaakkola JJ, Parise H, Kislitsin V, et al. Asthma, wheezing, and allergies in Russian schoolchildren in relation to new surface materials in the home. Am J Public Health 2004:94:560-2.

24 Jaakkola JJ, Oie L, Nafstad P, et al. Interior surface materials in the home and the development of bronchial obstruction in young children in Oslo, Norway. Am J Public Health 1999:89:188-92.

25 Delfino RJ, Gong H, Linn WS, et al. Respiratory symptoms and peak expiratory flow in children with asthma in relation to volatile organic compounds in exhaled breath and ambient air. $J$ Expos Anal Environ Epidemiol 2003;13:348-63.

The basis of this work is careful molecular dissection of precisely why coughing occurs when irritants are inhaled. It has been known for years that irritants such as citric acid and capsaicin (the pungent tongue burning constituent of hot chilli peppers) trigger coughing. It has also been known for decades from electrophysiological studies that such irritants activate respiratory tract sensory fibres-especially unmyelinated C fibres-to discharge information via the vagus to the medullary cough centre. ${ }^{3}$ From this early work it was inferred that the cough receptor on sensory fibres might be an ion channel able to rapidly depolarise afferent nerve membranes and hence trigger cough inducing impulses. This view was reinforced by the inhibitory activity of crude agents such as the dye ruthenium red. The discovery that capsazepine, a capsaicin derivative and a known ion channel blocker, had antitussive activity in animal models ${ }^{4}$ focused attention on the vanilloid receptor family as candidate ion channels. 
The TRPVl channel is a so-called receptor operated ion channel. It is moulded from six transmembrane domains that cluster forming a molecular "gate" which regulates the flow of cations across membranes when activated by a soluble ligand. TRPVI is encoded on chromosome 17pl3.3 and is also known as the capsaicin receptor, and the vanilloid receptor subtype 1 (VRl). This channel has been of interest to pain researchers for some time as it is known that the TRPVI channel can be activated by painful heat $\left(>43^{\circ} \mathrm{C}\right)$ and acid $(\mathrm{pH}<6.5)$. Its expression, however, is not confined to sensory nerves; TRPVI has also recently been found on glial cells, endothelium, epithelium and keratinoctyes, suggesting that it may have a much broader role in regulating responses to tissue injury. Indeed, as there is no good evolutionary reason why the lower lung should respond to hot pepper extracts, it has been strongly suspected that there must be one or more endogenous ligands for TRPVI. To date, three putative "endovanilloids" including $\mathrm{N}$-acyldopamines, arachidonic acid lipoxygenase metabolites, and anandamide (the endogenous ligand for cannabis receptors) have been identified. ${ }^{5}$ It is quite conceivable that these endoligands may be upregulatedtogether with kinins, histamine, and other known cough triggers-in lung diseases, but their specific relationship to cough is unknown.

TRPVl therefore has the attraction of being a common activation point for coughing induced by different stimuli. As always, there are caveats. The cough reflex has important survival benefits and it is likely that multiple cough pathways have co-evolved. Mice breathe too rapidly and too shallowly to generate the airflow turbulence necessary to clear mucus by coughing, but they have a highly conserved afferent fibre TRPVI which has strong homology with the human form. Elegant research by Kollarik and Undem ${ }^{6}$ has very recently identified TRPVI independent discharges in bronchopulmonary vagal afferent fibres to bradykinin and acid in TRPVl knock-out mice, indicating that at least one "back up" mechanism must exist. These findings are consistent with earlier studies showing that capsazepine did not block all cough inducing stimuli. ${ }^{4}$ It is also clear that patients with chronic cough have a reduced threshold for stimulation of cough, most probably because their afferent sensory fibres have become sensitised in a manner analogous to hyperalgesia in chronic pain. It is thought that this sensitisation may have both a peripheral and a CNS component. The role of TRPVI in the induction or reversal of sensitisationwhich may underlie very intractable cough-remains unknown. Moreover, the causes of cough in humans range from the physiological to the existential. While it is reasonable to hope that TRPVI targeted treatments might benefit cough in very common clinical settings such as chronic obstructive pulmonary disease, post-viral cough syndromes, and cough associated with gastro-oesophageal reflux disease, it seems unlikely that the concept would benefit "psychogenic" cough at all.
Notwithstanding these limitations, the work of Trevisani and coworkers showing a therapeutic benefit of inhibiting TRPVI with iodo-resiniferatoxin (and the more than 60 patents already filed in this field) suggests that there may soon be safer and more effective agents to deal with this perennial problem.

Thorax 2004;59:730-731.

doi: $10.1136 /$ thx.2003.016782

Correspondence to: Associate

Professor G P Anderson, PhD, Lung Disease Research Laboratories, Research Director, CRC for Chronic Inflammatory Diseases

Departments of Pharmacology and Medicine, University of Melbourne, Parkville, VIC 3010, Australia; gpa@unimelb.edu.au

Funded by the National Health and Medical Research Council (NHMRC) of Australia and the Cooperative Research Center (CRC) for Chronic Inflammatory Diseases.

\section{REFERENCES}

1 Schroeder K, Fahey T, Over-the-counter medications for acute cough in children and adults in ambulatory settings (Cochrane Review). In: The Cochrane Library. Chichester: John Wiley \& Sons, 2004

2 Trevisani M, Milan A, Gatti R, et al. Antitussive activity of iodo-resiniferatoxin in guinea pigs. Thorax 2004;59:769-72.

3 Coleridge JC, Coleridge HM. Lower respiratory tract afferents stimulated by inhaled irritants. Am Rev Respir Dis 1985;131:S51-4.

4 Lalloo UG, et al. Capsazepine inhibits cough induced by capsaicin and citric acid but not by hypertonic saline in guinea pigs. J Appl Physiol 1995;79:1082-7.

5 Van Der Stelt M, Di Marzo V. Endovanilloids. Putative endogenous ligands of transient receptor potential vanilloid 1 channels. Eur J Biochem 2004;271:1827-34.

6 Kollarik M, Undem BJ. Activation of bronchopulmonary vagal afferent nerves with bradykinin, acid and vanilloid receptor agonists in wild-type and TRPV1-/- mice. J Physiol 2004;555(Pt 1):115-23.

\section{Pneumocystis jirovecii infection \\ R Miller, L Huang}

\section{A review of Pneumocystis and the rationale for renaming it}

T he organism Pneumocystis causes severe pneumonia in individuals with immune systems impaired by HIV, transplantation, malignancy, connective tissue disease, and the treatment thereof. In HIV infected patients it remains a major pathogen in those who are unaware of their HIV serostatus, or who decline to take or are intolerant of highly active antiretroviral therapy. Pneumocystis also infects a wide variety of mammals and causes pneumonia in those that are immunosuppressed or immunodeficient. Originally Pneumocystis was thought to be a single species of protozoa. Study of the organism has been severely hampered by the fact that it cannot be cultured in vitro. Over the last 20 years, using molecular biological, immunological and other techniques, Pneumocystis has been shown to be a fungus, to be genetically diverse, host species specific, transmissible from animal to animal, to colonise individuals with minor degrees of immunosuppression, and to cause clinical disease by "new" infection in addition to reactivation of latent childhood acquired infection. More recently the organism causing disease in humans has been renamed Pneumocystis jirovecii. This article highlights some of these recent developments and provides a rationale for the renaming of the organism.

\section{WHAT IS PNEUMOCYSTIS?}

Chagas first identified Pneumocystis organisms in humans in 1909, but they were mistaken for a new stage of the life cycle of the protozoan Trypanosoma cruzi. ${ }^{1}$ Within a very short time it became apparent that the organism infected other host species, was not a trypanosome, and was named 
Pneumocystis carinii in honour of Carini, a colleague of Chagas. ${ }^{2}$ For many years the organism continued to be widely viewed as a protozoan, based on the observations that it had morphological features of protozoa and lacked some phenotypic features typical of fungi, and that antiprotozoal but not antifungal drugs were effective. In 1988 DNA sequence analysis showed that Pneumocystis was a fungus. ${ }^{3}$ Subsequently, additional DNA analysis at many loci has shown that Pneumocystis organisms from different mammalian hosts are quite different. ${ }^{5-7}$ It is also apparent that Pneumocystis shows strong host species specificity-for example, it is not possible to cross infect a mouse with Pneumocystis from a $\mathrm{rat}^{8}$ yet, if Pneumocystis obtained from the lungs of one rat is transferred to another rat, it will cause severe pneumonia. One explanation for these observations is that Pneumocystis is an obligate parasite which has co-evolved in a particular host in order to survive." The above data further indicate that human Pneumocystis infection is not a zoonosis. DNA sequence analysis of human Pneumocystis at several different loci has demonstrated genetic diversity in the organism ${ }^{7011}$ and has shown that two or more types of organism infect some patients with Pneumocystis pneumonia. ${ }^{711}$

\section{HOW DOES HUMAN INFECTION ARISE?}

It was originally thought that Pneumocystis organisms were acquired during childhood and persisted in the lungs in adult life in a dormant phase. Immunosuppression of the individualfor example, by transplantation or by HIV infection-allowed the organism to propagate and cause pneumonia. The finding of antibodies to Pneumocystis in the majority of healthy children ${ }^{12}$ and the strong association of disease with immunosuppression support this "latency" hypothesis. This hypothesis has been challenged by studies showing a lack of Pneumocystis in the lungs of healthy individuals ${ }^{13}$ and by studies which showed that Pneumocystis organisms are frequently acquired and cleared by the immune system of immune competent humans. ${ }^{14}$ Animal studies also challenge the "latency" hypothesis. In rat and severe combined immunodeficiency (SCID) mice models of infection, Pneumocystis organisms are eliminated from the lungs after Pneumocystis pneumonia and persistence of latent organisms is limited..$^{15} 16$ Limited asymptomatic carriage of Pneumocystis has been demonstrated in some HIV immunosuppressed adults; during carriage a change in genotype was observed, strongly supporting a hypothesis of "recent infection". ${ }^{17}$ Further support for the "recent infection" model comes from studies of patients with recurrent episodes of Pneumocystis pneumonia in which a different genotype of Pneumocystis was associated with each episode. ${ }^{18}{ }^{19}$ Recent infection is suggested by the finding that allelic variation patterns in isolates of Pneumocystis are correlated with patient's place of diagnosis and not their place of birth. ${ }^{20}$ The target enzyme for sulpha drugs (sulphamethoxazole, dapsone, etc) is dihydropteroate synthase (DHPS). In many organisms, including protozoa such as Plasmodium falciparum and bacteria such as Streptococcus pneumoniae, mutations in the DHPS gene confer resistance to sulpha drugs. Several studies have shown a significant association between patients' receipt of sulpha drug prophylaxis and the presence of mutations in the DHPS gene of Pneumocystis. ${ }^{21} 22$ These mutations also correlate with geographical location ${ }^{22} 23$ and may additionally be found in Pneumocystis from patients who have not received sulpha drug prophylaxis, suggesting that recent transmission has occurred, either directly person to person or via a common environmental source..$^{23-25}$

In animal models airborne transmission of Pneumocystis has been demonstrated $^{26}$ but the route of transmission of human Pneumocystis is unclear. Human Pneumocystis DNA has been identified in air spores from both rural $^{27}$ and hospital environments, ${ }^{28}$ and it is likely that transmission between humans occurs via the airborne route. This hypothesis is supported by reports of case clusters of Pneumocystis pneumonia among immunosuppressed patients, ${ }^{29}$ transmission of Pneumocystis DNA from immunosuppressed patients to immune competent healthcare workers, ${ }^{14}{ }^{30}$ and mother to child transmission of Pneumocystis infection. $^{31}$

\section{COLONISATION AND THE HUMAN RESERVOIR OF INFECTION}

Increasingly sensitive techniques have been developed for detecting Pneumocystis DNA in human respiratory samples (bronchoscopic alveolar lavage fluid, induced sputum, and oropharyngeal washes) using the polymerase chain reaction..$^{11} 131432$ This sensitivity has enabled detection of very low levels of Pneumocystis, not detectable by conventional histochemical staining, in respiratory samples from individuals in whom it was not expected. Molecular detection techniques have shown that
Pneumocystis is carried in the lungs of asymptomatic individuals with mild immunosuppression induced by HIV or malignancy, ${ }^{33-36}$ in immune competent patients ${ }^{37}$ with primary pulmonary disorders, $^{38}$ in patients receiving long term corticosteroid therapy for malignancy or connective tissue disorders, ${ }^{39} 40$ and in pregnant women. ${ }^{41}$ It is thought that detection of Pneumocystis in respiratory samples from these asymptomatic patient groups represents colonisation with the organism. It is further hypothesised that these groups of patients may be important in the person to person transmission of Pneumocystis and that they may be a reservoir for future Pneumocystis infection in other susceptible (immunosuppressed) individuals. ${ }^{17}$

\section{WHY RENAME PNEUMOCYSTIS CARINII?}

In 1994, in response to the accumulation of molecular biological data demonstrating genetic diversity among isolates of Pneumocystis from different host species together with data from cross infection studies suggesting host species specificity, an interim renaming of Pneumocystis carinii occurred using a trinomial system. ${ }^{42}$ Thus the organism causing infection in humans was named Pneumocystis carinii f. sp. hominis and that causing infection in rats was called Pneumocystis carinii f. sp. carinii. In 1999 a binomial system was proposed for naming the organism. ${ }^{43}$ The organism producing human disease is now known as Pneumocystis jirovecii (pronounced "yee-row-vetsee") in honour of the Czech parasitologist Otto Jírovec who was one of the first researchers to study Pneumocystis in humans. ${ }^{44} 45$ This renaming not only recognises the host specificity of different species of Pneumocystis for different mammalian hosts, but also the significant differences that exist among different species of Pneumocystis at a DNA sequence level. Pneumocystis carinii is now the name used to describe infection in rats and is not infectious to humans. ${ }^{44}{ }^{45}$ The acronym "PCP" which is used to describe the clinical syndrome of pneumonia in both humans and other mammals is still used, but it now represents $\underline{\mathbf{P} n e u m o}$ Cystis $\underline{\mathbf{P} n e u m o n i a . ~ P h y s i c i a n s}$ and patients will be reassured by the knowledge that human infection does not arise in-nor can it be transmitted to-domestic animals, and by the fact that, despite the name change, the clinical disease remains "PCP".

Thorax 2004;59:731-733

doi: $10.1136 /$ thx.2004.021436 


\section{Authors' affiliations}

R Miller, Centre for Sexual Health and HIV Research, Department of Primary Care and Population Sciences, Royal Free and University College Medical School, University College London, London WC1E 6AU, UK

L Huang, Positive Health Programme and Division of Pulmonary and Critical Care Medicine, San Francisco General Hospital, Department of Medicine, University of California San Francisco, San Francisco, CA 94110, USA

Correspondence to: Dr R Miller, Centre for Sexual Health and HIV Research, Department of Primary Care and Population Sciences, Royal Free and University College Medical School, University College London, London WCIE 6AU, UK; rmiller@gum.ucl.ac.uk

Dr Miller is supported by Camden PCT, UK and Dr Huang is supported by the National Institutes of Health, USA, grant no K23 HL072117.

\section{REFERENCES}

1 Chagas C. Uber eine neve Typanosomiasis des Menschen. Mem Inst Oswaldo Cruz 1909;3:1-218.

2 Delanoë P, Delanoë M. Sur les rapports des kystes de Carini du poumon des rats avec le Trypanosoma lewisi. C R Acad Sci 1912;155:658-61.

3 Edman JC, Kovacs JA, Masur H, et al. Ribosomal RNA sequence shows Pneumocystis carinii to be a member of the fungi. Nature 1988:334:519-22.

4 Stringer SL, Stringer JR, Blase MA, et al. Pneumocystis carinii: sequence from ribosomal RNA implies a close relationship with fungi. Exp Parasitol 1989:68:450-61.

5 Sinclair K, Wakefield AE, Banerii S, et al. Pneumocystis carinii organisms derived from rat and human hosts are genetically distinct. Mol Biochem Parasitol 1991:45:183-4.

6 Mazars E, Odberg-Ferragut C, Dei-Cas E, et al. Polymorphism of the thymidylate synthase gene of Pneumocystis carinii from different host species. J Eukaryot Microbiol 1995;42:26-32.

7 Banerii S, Lugli EB, Miller RF, et al. Analysis of genetic diversity at the arom locus in isolates of Pneumocystis carinii. J Eukaryot Microbiol 1995;42:675-9.

8 Aliouat EM, Mazars E, Dei-Cas E, et al. Pneumocystis cross infection experiments using SCID mice and nude rats as recipient host showed strong host-species specificity. J Eukarot Microbiol 1994;41:71S

9 Demanche C, Berthelemy M, Petit T, et al. Phylogeny of Pneumocystis carinii from 18 primate species confirms host specificity and suggests co-evolution. J Clin Microbio 2001:39:2126-33.

10 Tsolaki AG, Beckers P, Wakefield AE. Pre-AIDS isolates of Pneumocystis carinii f. sp. hominis: high genotypic similarity with contemporary isolates, J Clin Microbiol 1998:36:90-3.

11 Miller RF, Lindley AR, Ambrose HE, et al. Multilocus genotyping of Pneumocystis jiroveci from adult patients with Pneumocystis pneumonia $J$ Eukaryot Microbiol 2003;50:654-5S.
12 Wakefield AE, Stewart TJ, Moxon ER, et al. Infection with Pneumocystis carinii is prevalent in healthy Gambian children. Trans R Soc Trop Med Hyg 1990;84:800-2.

13 Wakefield AE, Pixley FJ, Banerii S, et al. Detection of Pneumocystis carinii with DNA detection. Lancet 1990;336:451-3.

14 Miller RF, Ambrose HE, Wakefield AE. Pneumocystis carinii f. sp. hominis DNA in immunocompetent health care workers in contact with patients with Pneumocystis carinii pneumonia. J Clin Microbiol 2001;39:3877-82.

15 Vargas S, Hughes WT, Wakefield $A E$, et al. Limited persistence in and subsequent elimination of Pneumocystis carinii from the lungs after $P$ carinii pneumonia. $J$ Infect Dis 1995; 172:506-10.

16 Chen W, Gigliotti F, Harmsen AG. Latency is not an inevitable outcome of infection with Pneumocystis carinii. Infect Immun 1993;61:5406-9

17 Wakefield AE, Lindley AR, Ambrose HE, et al. Limited asymptomatic carriage of Pneumocystis jiroveci in human immunodeficiency virus-infected patients. J Infect Dis 2003;187:901-8.

18 Keely SP, Stringer JR, Baughman RP, et al. Genetic variation among Pneumocystis carini hominis isolates in recurrent pneumocystosis. $J$ Infect Dis 1995; 172:595-8.

19 Tsolaki AG, Miller RF, Underwood AP, et al. Genetic diversity at the internal transcribed spacer regions of the rRNA operon among isolates of Pneumocystis carinii from AIDS patients with recurrent pneumonia. J Infect Dis 1996;174:141-56.

20 Beard CB, Carter JL, Keely SP, et al. Genetic variation in Pneumocystis carinii isolates from different geographic regions: implications for transmission. Emerg Infect Dis 2000;6:265-72.

21 Kazaniian P, Armstrong W, Hossler PA, et al. Pneumocystis carinii mutations are associated with duration of sulfa or sulfone prophylaxis exposure in AIDS patients. $J$ Infect Dis 2000; 182:551-7.

22 Huang L, Beard CB, Creasman J, et al. Sulfa or sulfone prophylaxis and geographic region predict mutations in the Pneumocystis carinii dihydropteroate synthase gene. $J$ Infect Dis 2000; 182:1 192-8.

23 Huang L, Friedly J, Morris AM, et al. Pneumocystis carinii dihydropteroate synthase genotypes in HIV-infected persons residing in San Francisco: possible implications for disease ransmission. J Eukaryot Microbio 2001;48:137S-8S

24 Miller RF, Lindley AR, Ambrose HE, et al. Genotypes of Pneumocystis jiroveci isolates obtained in Harare, Zimbabwe and London, United Kingdom. Antimicrob Agents Chemother 2003;47:3979-81.

25 Crothers K, Huang L, Morris A, et al. Pneumocystis dihydropteroate synthase mutations in patients with Pneumocystis pneumonia who are newly diagnosed with HIV infection. J Eukaryot Microbiol 2003;50:609S-10S.

26 Dumoulin A, Mazars E, Seguy N, et al. Transmission of Pneumocystis carinii disease from immunocompetent contacts of infected hosts to susceptible hosts. Eur J Clin Microbiol Infect Dis 2000; 19:671-8.

27 Wakefield AE. DNA sequences identical to Pneumocystis carinii $f$. sp. carinii and Pneumocystis carinii f. sp. hominis in samples of air spora. J Clin Microbiol 1996;34:1754-9.
28 Bartlett MS, Vermund SH, Jacobs R, et al. Detection of Pneumocystis carinii DNA in air samples: likely environmental risk to susceptible persons. J Clin Microbiol 1997;31:251 1-3.

29 Helweg-Larsen J, Tsolaki AG, Miller RF, et al. Clusters of Pneumocystis carinii pneumonia: analysis of person to person transmission by genotyping. Q J Med 1998;91:813-20.

30 Vargas SL, Ponce CA, Gigliotti F, et al. Transmission of Pneumocystis carinii DNA from a patient with $\mathrm{P}$ carinii pneumonia to immunocompetent health care workers. J Clin Microbiol 2000;38:1536-8

31 Miller RF, Ambrose HE, Novelli V, et al. Probable mother-to-infant transmission of Pneumocystis carinii f. sp. hominis infection. J Clin Microbiol 2002;40:1555-7.

32 Tsolaki AG, Miller RF, Wakefield AE. Oropharyngeal samples for genotyping and monitoring of response to treatment in AIDS patients with Pneumocystis carinii pneumonia. J Med Microbiol 1999;48:897-905.

33 Leigh TR, Kangro HO, Gazzard BG, et al. DNA amplification by the polymerase chain reaction to detect sub-clinical Pneumocystis carinii colonization in HIV-positive and HIV-negative homosexuals with and without respiratory symptoms. Respir Med 1993;87:525-9.

34 Nevez G, Raccurt $C$, Jounieaux $V$, et al. Pneumocystosis versus pulmonary Pneumocystis carinii colonization in HIV-negative and HIVpositive patients. AIDS 1999;13:535-6.

35 Huang L, Crothers K, Morris A, et al. Pneumocystis colonization in HIV-infected patients. J Eukaryot Microbiol 2003;50:616-7S.

36 Morris A, Kingsley LA, Groner G, et al. Prevalence and clinical predictors of Pneumocystis colonization among HIV-infected men. AIDS 2004; 18:793-8.

37 Armbruster C, Hassl A, Kriwanek S. Pneumocystis carinii colonization in the absence of immunosuppression. Scand J Infect Dis 1997:29:591-3.

38 Sing A, Roggenkamp A, Autenrieth IB, et al. Pneumocystis carinii carriage in immunocompetent patients with primary pulmonary disorders as detected by single or nested PCR. J Clin Microbiol 1999;37:3409-10.

39 Maskell NA, Waine DJ, Lindley A, et al. Asymptomatic carriage of Pneumocystis jiroveci in subjects undergoing bronchoscopy: a prospective study. Thorax 2003;58:594-7.

40 Helweg-Larsen J, Jensen JS, Dohn B, et al Detection of Pneumocystis DNA in samples from patients suspected of bacterial pneumonia: a case-control study. BMC Infect Dis 2002;2:28

41 Vargas SL, Ponce CA, Sanchez CA, et al. Pregnancy and asymptomatic carriage of Pneumocystis jiroveci. Emerg Infect Dis 2003;9:605-6.

42 The Pneumocystis Workshop. Revised nomenclature for Pneumocystis carinii. J Eukaryot Microbiol 1994:41:121-2S.

43 Frenkel JK. Pneumocystis pneumonia, an immunodeficiency dependent disease (IDD): a critical historical overview. J Eukaryot Microbiol 1999:46:89-92S.

44 Stringer JR, Cushion MT, Wakefield AE. New nomenclature for Pneumocystis carinii. Proceedings of the Seventh International Workshops on Opportunistic Protists. J Eukaryot Microbiol 2001;48:184-9S

45 Stringer JR, Beard CB, Miller RF, et al. A new name (Pneumocystis jiroveci) for Pneumocystis from humans. Emerg Infect Dis 2002;8:891-6. 
Inflammatory cells and airway dysfunction

\section{Location, location, location: microlocalisation of inflammatory cells and airway dysfunction}

\section{E Brightling, I D Pavord}

Role of inflammatory cell location in the pathogenesis of asthma, COPD, and cough

$M$ ost inflammatory mediators are rapidly inactivated once they leave the cell so that they act across distances of only a few microns. It is therefore likely that microlocalisation between inflammatory and structural cells is a fundamental organising principle of airway inflammation and repair.

Enthusiasm for the view that microlocalisation is important in obstructive airway diseases has been fuelled by studies which showed inflammatory cells within the airway smooth muscle in asthma and chronic obstructive pulmonary disease (COPD) but not in normal controls. In asthma the airway smooth muscle is infiltrated by mast cells, predominantly of the chymase positive phenotype. Mast cell numbers correlate inversely with airway responsiveness, ${ }^{1}$ which suggests that interactions between mast cells and smooth muscle cells are central in the development of the disordered physiology in asthma. The strength of this assertion is underpinned by the paucity of mast cells within the airway smooth muscle in eosinophilic bronchitis, a condition that presents with chronic cough and shares many of the immunopathological features of asthma but is not associated with airflow obstruction or airway hyperresponsiveness. ${ }^{1-3}$ Importantly, there is evidence that mast cells infiltrating the airway smooth muscle bundle are activated; a necroscopic study of fatal and non-fatal asthma has shown that there is a marked increase in mast cell degranulation in the airway smooth muscle in both the large and small airways. ${ }^{4}$

A recent study has investigated whether a similar phenomenon occurs in COPD. Baraldo et $a l^{5}$ found increased numbers of neutrophils and CD8+ cells-but not mast cells-in the small airways of smokers with COPD, and the neutrophil number was inversely related to percentage predicted forced expiratory volume in 1 second $\left(\mathrm{FEV}_{1}\right)$. This is consistent with an earlier study which showed that the number of neutrophils in the airway smooth muscle in smokers is related to air trapping as determined by CT scanning. ${ }^{6}$ However, in this study Berger et al found that the number of chymase positive mast cells was more closely related with air trapping. Most of the subjects in these studies had undergone lung resection for cancer so, although the airways studied were considered to be from unaffected areas, there remains the possibility that the underlying lung cancer contributed to the inflammatory changes. Nevertheless, the body of evidence strongly suggests that microlocalisation of inflammatory cells within the airway smooth muscle bundle is an important feature of obstructive airway diseases. This raises two key questions:

- Why do specific inflammatory cells accumulate in the airway smooth muscle in asthma and COPD?

- How do interactions between these inflammatory cells and airway smooth muscle cells lead to disordered airway function?

\section{WHY DO SPECIFIC INFLAMMATORY CELLS ACCUMULATE IN THE AIRWAY SMOOTH MUSCLE IN ASTHMA AND COPD?}

Selective recruitment of inflammatory cells to the airway smooth muscle is likely to be mediated by smooth muscle derived chemoattractants and by maintenance of the correct microenvironment to maintain cell differentiation and survival. Airway smooth muscle has a significant secretory capacity, so it clearly has the potential to recruit inflammatory cells. ${ }^{7}$ For example, CXCL8 (IL-8) and CXCL10 (IP-10) released by activated airway smooth muscle in COPD may mediate neutrophil and CD8+ cell migration into the airway smooth muscle bundle. $^{89} \mathrm{~A}$ plethora of chemotactic factors for mast cells are released by airway smooth muscle-notably, stem cell factor (SCF), ${ }^{10}$ CCL11 (eotaxin), ${ }^{11}$ CXCL8 (IL$8),{ }^{8}$ and transforming growth factor (TGF)- $\beta .^{10}$ We have recently shown that CXCR3 is the most abundantly expressed chemokine receptor on human lung mast cells within airway smooth muscle, that human lung mast cell migration is induced by the CXCR3 ligand CXCL10, and that CXCL10 is released preferentially from asthmatic airway smooth muscle cells compared with those from healthy controls. ${ }^{12}$ Future studies investigating the effects of inhibiting this pathway will be of particular interest.

It is likely that a number of other chemokines play a role in the recruitment of inflammatory cells into the airway and it may be that the release of chemotaxins by airway smooth muscle varies in response to different stimuli such as cigarette smoke, infection, or allergen exposure. Future studies should explore the relative importance of these triggers and the associated chemotaxins that are released in promoting inflammatory cell infiltration into the airway smooth muscle. It is also important to investigate why some inflammatory cells, notably eosinophils, are rarely seen in the airway smooth muscle in spite of appropriate chemotactic signals.

\section{HOW DO INTERACTIONS BETWEEN THESE INFLAMMATORY CELLS AND AIRWAY SMOOTH MUSCLE CELLS LEAD TO DISORDERED AIRWAY FUNCTION?}

Activation of the inflammatory cells within the airway smooth muscle bundle would be predicted to have important consequences on airway smooth muscle function. Following mast cell degranulation the mediators histamine, $\mathrm{PGD}_{2}$ and $\mathrm{LTC}_{4}$ are released which are all potent agonists for airway smooth muscle contraction. ${ }^{13}$ Mast cell cytokines may further contribute to airway hyperreponsiveness. The mast cells in the airway smooth muscle bundles in asthma express IL-13,14 and IL-13 has been shown to attenuate relaxation to $\beta$ agonists and to augment contractility to acetylcholine..$^{15}{ }^{16}$ The effect of neutrophil derived mediators on airway smooth muscle function is less clear, with conflicting reports from animal studies showing that elastase can increase and diminish smooth muscle responsiveness. ${ }^{17}{ }^{18}$

The interactions between inflammatory cells and airway smooth muscle cells may have more long term consequences. A number of mast cell mediators including histamine, ${ }^{19}$ tryptase, ${ }^{20}$ and $\mathrm{LTD}_{4}{ }^{21}$ as well as the neutrophil product elastase, ${ }^{22}$ promote airway smooth muscle proliferation. Increased 
airway smooth muscle mass is a well established feature of both asthma ${ }^{23}$ and COPD. ${ }^{24}$ In asthma this occurs predominantly in the large airway and in COPD in the small airways. A study using a computational model of the effects of increased muscle mass has suggested that it is the most important abnormality responsible for the increased airflow resistance observed in response to bronchoconstricting stimuli in both asthma and COPD. ${ }^{25}$ The relative contribution of airway wall smooth muscle mass to overall airway wall thickness in the small airways is much greater than that in the large airways. Thus, increased smooth muscle mass in the small airways is likely to make a significant contribution to the development of fixed airflow obstruction characteristic of COPD and sometimes seen in persistent chronic severe asthma. The role of interactions between inflammatory cells and smooth muscle cells in the development of airway wall remodelling in asthma and COPD offers exciting opportunities for future research.

\section{FUTURE STUDIES}

The recognition of the importance of microlocalisation is not confined to inflammatory cells and airway smooth muscle cells but is probably equally critical in interactions with other structural cells such as the epithelium, fibroblasts, mucosal glands, and nerve cells. Eosinophilic bronchitis, cough variant asthma, and idiopathic chronic cough are associated with increased concentration of mast cell products in sputum, ${ }^{26}{ }^{27}$ and we have suggested that localisation of mast cells to sensory nerve endings might be important in the development of cough reflex hypersensitivity and cough. A rather similar interaction is thought to be important in the genesis of itch. ${ }^{28} 29$ Understanding the fundamental steps that are involved in the migration of inflammatory cells towards structural cells such as the airway smooth muscle and the interactions between these cells may provide us with novel targets for the future treatment of asthma, COPD, and cough.
Researchers interested in the immunopathology of airway diseases therefore need to be mindful of the importance of "location, location, location".

Thorax 2004;59:734-735.

doi: $10.1136 /$ thx.2004.026328

\section{Authors' affiliations}

C E Brightling, I D Pavord, Institute for Lung Health, University of Leicester, Division of

Respiratory Medicine, Leicester, UK

Correspondence to: Dr I D Pavord, Institute for Lung Health, Department of Respiratory Medicine, University Hospitals of Leicester, Groby Road, Leicester LE3 9QP, UK;

ian.pavord@uhl-tr.nhs.uk

\section{REFERENCES}

1 Brightling CE, Bradding P, Symon FA, et al. Mastcell infiltration of airway smooth muscle in asthma. N Engl J Med 2002;346:1699-705

2 Brightling CE, Ward R, Goh KL, et al. Eosinophilic bronchitis is an important cause of chronic cough Am J Respir Crit Care Med 1999;160:406-10.

3 Brightling CE, Symon FA, Birring SS, et al. Comparison of airway immunopathology of eosinophilic bronchitis and asthma. Thorax 2003;58:528-32.

4 Carroll NG, Mutardzic S, James AL. Distribution and degranulation of airway mast cells in normal and asthmatic subjects. Eur Respir J 2002; 19:879-85.

5 Baraldo S, Turato G, Badin C, et al. Neutrophilic infiltration within the airway smooth muscle in patients with COPD. Thorax 2004;59:308-12.

6 Berger $\mathbf{P}$, Laurent $F$, Begueret $H$, et al. Structure and function of small airways in smokers: relationship between air trapping at CT and airway inflammation. Radiology 2003;228:85-94.

7 Knox AJ, Pang L, Johnson S, et al. Airway smooth muscle function in asthma. Clin Exp Allergy 2000;30:606-14.

8 John M, Au BT, Jose PJ, et al. Expression and release of interleukin- 8 by human airway smooth muscle cells: inhibition by Th-2 cytokines and corticosteroids. Am J Respir Cell Mol Bio 1998; 18:84-90.

9 Hardaker EL, Bacon AM, Carlson KA, et al. Regulation of TNF- $\alpha$ - and IFN- $\gamma$-induced CXCL10 expression: participation of the airway smooth muscle in the pulmonary inflammatory response in chronic obstructive pulmonary disease. FASEB J 2004; 18:191-3

10 Berger P, Girodet O, Begueret $\mathrm{H}$, et al. Tryptasestimulated human airway smooth muscle cells induce cytokine synthesis and mast cell chemotaxis. FASEB J 2003;17:2139-41

11 Hirst SJ, Hallsworth MP, Peng O, et al. Selective induction of eotaxin release by interleukin- 13 or interleukin- 4 in human airway smooth muscle cells is synergistic with interleukin-1 $\beta$ and is mediated by the interleukin- 4 receptor $\alpha$-chain. Am J Respir Crit Care Med 2002;165:1161-71.

12 Brightling CE, Ammitt AJ, Berger $\mathrm{P}$, et al. CXCL10 (IP-10) is a novel mast cell chemokine and is released by asthmatic airway smooth muscle (abstract). Thorax 2003;58(Suppl III):iii4-5.

13 Brightling CE, Bradding P, Pavord ID, et al. New insights into the role of the mast cell in asthma. Clin Exp Allergy 2003:33:550-6.

14 Brightling CE, Symon FA, Holgate ST, et al. Interleukin-4 and - 13 expression is co-localized to mast cells within the airway smooth muscle in asthma. Clin Exp Allergy 2003;33:1711-6.

15 Grunstein MM, Hakonarson $\mathrm{H}$, Leiter J, et al. IL13 dependent autocrine signalling mediates altered responsiveness of IgE-sensitized airway smooth muscle. Am J Physiol Lung Cell Mol Physiol 2002;282:520-8.

16 Laporte JC, Moore PE, Baraldo S, et al. Direc effects of interleukin-13 on signaling pathways for physiological responses in cultured human airway smooth muscle cells. Am J Respir Crit Care Med 2001;164:141-8.

17 Gray PR, Mitchell HW. Intramural elastase injection increases responsiveness of isolated bronchial segments. Pulm Pharmacol 1996;9:239-43.

18 Christensen GC, Lev A, Ryan J, et al. Rabbit trachealis tension responses to receptor-mediated agonists are diminished by elastase. Am J Respir Cell Mol Biol 1992;6:498-503.

19 Panettieri RA Jr, Yadvish PA, Kelly AM, et al. Histamine stimulates proliferation of airway smooth muscle and induces c-Fos expression. Am J Physiol 1990;259:L365-71.

20 Berger P, Perng DW, Thabrew H, et al. Tryptase and agonists of PAR-2 induce the proliferation of human airway smooth muscle. J Appl Physiol 2001;91:1372-9.

21 Espinosa K, Bosse Y, Stankova J, et al. CysLT1 receptor upregulation by TGF-beta and IL-13 is associated with bronchial smooth muscle cell proliferation in response to LTD4. J Allergy Clin Immunol 2003;111:1032-40.

22 Huang $\mathrm{CD}$, Chen $\mathrm{HH}$, Wang $\mathrm{CH}$, et al. Human neutrophil-derived elastase induces airway smooth muscle cell proliferation. Life $\mathrm{Sci}$ 2004;74:2479-92.

23 Carroll N, Elliot J, Morton A, et al. The structure of large and small airways in nonfatal and fatal asthma. Am Rev Respir Dis 1993:147:405-10.

24 Saetta M, Di Stefano A, Turato G, et al. CD8+ Tlymphocytes in peripheral airways of smokers with chronic obstructive pulmonary disease. Am J Respir Crit Care Med 1998;157:822-6.

25 Lambert RK, Wiggs BR, Kuwano K, et al. Functional significance of increased airway smooth muscle in asthma and COPD. J Appl Physiol 1993;74:2771-81.

26 Brightling CE, Ward R, Woltmann $G$, et al. Induced sputum inflammatory mediator concentrations in eosinophilic bronchitis and asthma. Am J Respir Crit Care Med 2000; 162:878-82.

27 Birring SS, Parker D, Brightling CE, et al. Induced sputum inflammatory mediator concentrations in chronic cough. Am J Respir Crit Care Med 2004; 169:15-9.

28 Gibson PG. Cough is an airway itch? Am J Respir Crit Care Med 2004;169:1-2.

29 Yosipovitch G, Greaves MW, Schmelz M. Itch. Lancet 2003;361:690-4. 
Impact factor

\section{Journal impact factors for 2003: Thorax increases}

\section{J A Wedzicha, S L Johnston, D M Mitchell}

\section{The impact factor for Thorax is rising}

mpact factors for journals for the year 2003 have recently been published and we are delighted that the impact factor for Thorax has risen to 4.188. It is now the second highest ranked conventional respiratory journal in terms of impact factor, behind the American Journal of Respiratory and Critical Care Medicine, and has overtaken the American Journal of Respiratory Cell and Molecular Biology. The impact factors for the main respiratory journals are listed in table 1 .

The journal impact factor for 2003 reflects the number of citations in 2003 to papers published in Thorax in 2001 and 2002. Thorax is very fortunate in having received excellent papers for publication and this is reflected in the rise in the impact factor over the last few years. ${ }^{1}$ However, in addition to original papers in 2001 and 2002, Thorax published a number of high quality review articles such as the Year in Review supplement, ${ }^{2}$ critical care series, ${ }^{3}$ we started a series on $\mathrm{COPD}^{4}$ and one on lung cancer. ${ }^{5}$ In 2001 and 2002 we also published a number of guidelines which have important implications for clinical practice-such as guidelines for the management of community acquired pneumonia in adults and children, ${ }^{67}$ the use of non-invasive ventilation in acute respiratory failure, ${ }^{8}$ selection of patients with lung cancer for surgery, guidelines for flexible bronchoscopy, ${ }^{10}$ and on air travel. ${ }^{11}$ We would like to thank the previous Thorax editors, John Britton and Alan Knox, for their hard work ${ }^{12}$ and for their immense contribution to the current success of the journal.

The rise in impact factor reflects the continuing success of Thorax. Over the past year we have seen a marked rise in submissions, especially of high quality papers, ${ }^{13}$ and we very much urge you to continue to send us your best papers. The online submission Bench $>$ Press system means that the peer review process in the journal is now faster and our publication lag time is short. Thus, over the next few years we are

Table 1 Impact factors for respiratory journals: 2003

\begin{tabular}{ll} 
American Journal of Respiratory & 8.876 \\
and Critical Care Medicine & \\
Thorax & $\mathbf{4 . 1 8 8}$ \\
$\begin{array}{l}\text { American Journal of Respiratory } \\
\text { Cell and Molecular Biology }\end{array}$ & 4.015 \\
$\begin{array}{l}\text { American Journal of Physiology: } \\
\text { Lung Cellular and Molecular }\end{array}$ & 3.735 \\
$\begin{array}{l}\text { Pathology } \\
\text { Journal of Thoracic and }\end{array}$ & 3.319 \\
$\begin{array}{l}\text { Cardiovascular Surgery } \\
\text { Chest }\end{array}$ & 3.264 \\
$\begin{array}{l}\text { European Respiratory Journal } \\
\text { Journal of Heart and Lung }\end{array}$ & 2.999 \\
$\begin{array}{l}\text { Transplantation } \\
\text { Respiratory Medicine }\end{array}$ & 2.843 \\
& 1.419 \\
\hline
\end{tabular}

confident that the impact factor for Thorax will rise further, with the journal enjoying an increasing international profile while at the same time maintaining its important educational role.

Thorax 2004;59:736.

doi: 10.1136/thx.2004.031864

\section{Authors' affiliations}

J A Wedzicha, S L Johnston, D M Mitchell, Thorax Editorial Office, 17 Doughty Street, London WCIN 2PL, UK

Correspondence to: Professor J A Wedzicha, Thorax Editorial Office, 17 Doughty Street, London WCIN 2PL, UK; j.a.wedzicha@qmul. ac.uk

\section{REFERENCES}

1 Knox AJ, Britton J. Journal impact factors for 2000: Thorax flying yet higher. Thorax 2001;56:587.

2 Mitchell DM, Shaheen SO, Woodcock AA, eds. 2002 Year in Review: selected topics in respiratory medicine from 2001. Thorax 2002;57(Suppl II):ii1-68.

3 Griffiths JD, Evans TW. The pulmonary physician in critical care: towards comprehensive critical care. Thorax 2002;57:77-8.

4 Lomas DA. Chronic obstructive pulmonary disease. Introduction. Thorax 2002;57:735

5 Sethi T. Lung cancer. Introduction. Thorax 2002;57:992-3.

6 British Thoracic Society. BTS guidelines for the management of community acquired pneumonia in adults. Thorax 2001;56(Suppl IV):iv1-64.

7 British Thoracic Society. Guidelines for the management of community acquired pneumonia in childhood. Thorax 2002;57(Suppl I):i1-24.

8 British Thoracic Society. Non-invasive ventilation in acute respiratory failure. Thorax 2002;57:192-211.

9 British Thoracic Society, Society of Cardiothoracic Surgeons of Great Britain and Ireland Working Party. Guidelines on the selection of patients with lung cancer for surgery. Thorax 2001;56:89-108.

10 British Thoracic Society guidelines on diagnostic flexible bronchoscopy. Thorax 2001;56(Suppl):i1-21.

11 British Thoracic Society. Managing passengers with respiratory disease planning air travel: British Thoracic Society recommendations. Thorax 2002;57:289-304.

12 Knox AJ, Britton J. We're off: Annual report October 2001 to September 2002. Thorax 2002:57:1003-4.

13 Wedzicha JA, Johnston SL, Mitchell DM. Annual Report 2003. Thorax 2003;58:1015-7.

\section{Making Health Care Safer 2004}

21-22 October 2004

Royal College of Physicians, London

A two day conference for all professionals dedicated to providing safer health care for all.

Register now! Early booking discount available.

See website for details: www.quality.bmipg.com 